\title{
Septisk artritt
}

\author{
Villy Johnsen \\ Revmatologisk avdeling, Sørlandet sykehus, Kristiansand
}

\section{ENGLISH SUMMARY}

Johnsen V. Septic arthritis. Nor J Epidemiol 2008; 18 (1): 21-22.

\begin{abstract}
The incidence of septic arthritis in industrialized countries is 1.4-7 per 100000 of the population per year. The incidence is higher in children, in old people, in immunocompromized patients and patients treated with intrarticular injections and joint surgery. The incidence seems to be increasing due to intraarticular procedures. Infections with staphylococci, streptococci and pneumococci dominates in adults, Hemophilus influenzae and streptococci in children.
\end{abstract}

En rekke mikroorganismer kan invadere ledd og føre til artritt. I denne sammenhengen blir det fokusert på pussdannende bakterier som forårsaker det man i klinikken vanligvis kaller septisk artritt. Septisk artritt er vanligvis monartikulær, ikke sjelden oligoartikulær, men sjelden polyartikulær. Sykdomsbildet kan være stormende og dramatisk, men kan også være indolent, særlig hos eldre og svekkede individer. Et septisk bilde med derangering av interne organfunksjoner kan være meget alvorlig og krever intensivmedisinsk overvåkning. Diagnostisk avklaring må skje raskt og krever dyrkning av leddvæske eller synovialvev og blodkulturer. Differensialdiagnostikken omfatter bløtdelslidelser, krystallartritter, reaktive artritter og Vogt-Løfgrens syndrom.

\section{INSIDENS}

Årlig insidens pr. 100000 innbyggere varierer i industrialiserte land mellom 1,4 og 7, men er høyere under 15 års alder og over 55 års alder (1-3). Insidensen avhenger av inklusjonskriteriene. I en norsk studie fra 1993 var insidensen av bakteriologisk verifisert septisk artritt 1,4 pr. 100000 innbyggere (1). De fleste studier som er publisert, har ikke så strenge inklusjonskriterier. I en nylig publisert studie fra Island som omfattet 253 pasienter som var observert fra 1990 til 2002, var insidensen 7,1/100000 innbyggere, og insidensen hadde økt fra 4,2/100000 innbyggere i 1990 til 11/100000 innbyggere i 2002 (3). Insidensen av septisk artritt ved revmatoid artritt varierer i studier fra 28-38/100000 innbyggere, ved protesekirurgi fra 40-68/100000 innbyggere (4). TNF-blokkerende behandling gir økt infeksjonsrisiko generelt, men det foreligger ikke pålitelige data som angir insidensen av septisk artritt (5-7).

\section{Mikrobiologi}

Bakteriologiske funn avhenger av alder og tilgrunnliggende tilstand. Hemophilus influenzae og streptokokker dominerer hos små barn, mens gule stafylokokker, hvite koagulase-negative stafylokokker, streptokokker og pneumokokker dominerer hos voksne (13). Negative bakteriologiske undersøkelser varierer fra $55 \%$ hos barn til $18 \%$ hos voksne (3).

\section{LEDDAFFEKSJON}

Affeksjon av hofteledd og kneledd dominerer hos barn, mens affeksjon av knær dominerer hos voksne, men de fleste ledd kan affiseres (3).

\section{DISPONERENDE ÅRSAKER}

Alder er en viktig disponerende faktor. Sykdommer og medikamenter som svekker immunapparatet, er framtredende i alle materialer (1-7). Iatrogene årsaker som intraartikulære injeksjoner, artroskopier og proteseoperasjoner synes å være en viktig årsak til den økte insidensen man har observert på Island i perioden 1990-2002. Frekvensen av septisk artritt etter artroskopi var i denne perioden $0,14 \%$ og etter intraartikulære injeksjoner $0,037 \%$ (3).

\section{KONKLUSJON}

Septisk artritt er en sjelden, men farlig tilstand med en årlig insidens i den generelle befolkning på 1,4-7/ 100000. Insidensen er høyere hos barn, eldre, immunsupprimerte og individer utsatt for intraartikulære injeksjoner og leddkirurgi. Insidensen synes å være økende i takt med bruken av intraartikulære prosedyrer.

\section{REFERANSER}

1. Gran JT, Lund OD, Svenningsen S, Benestad Y. Bakteriell artritt. Tidsskr Nor Laegeforen 1993; 113: 581-4.

2. Cooper C, Cawley MID. Bacterial arthritis in an English health district: a 10 year review. Ann Rheum Dis 1986; 45: 458-63. 
3. Geirsson AJ, Statkivicius S, Vikingson A. Septic arthritis in Iceland 1990-2002. Increasing incidence due to iatrogenic infections. Ann Rheum Dis 2008 (In press, doi:10.1136/ard.2007.077131).

4. Kaandorp CJ, van Schaandenburg D, Krijnen JD et al. Risk factors for septic arthritis in patients with joint disease. A prospective study. Arthritis Rheum 1995; 38: 1819-25.

5. Strangfeld A, Listing J. Bacterial and opportunistic infections during anti-TNF therapy. Best Pract Res Clin Rheumatol 2006; 20 (6): 1181-95.

6. Dixon WG, Watson K, Lunt $\mathrm{M}$ et al. Rates of serious infections, including site-specific and bacterial intracellular infections, in rheumatoid arthritis patients receiving anti-tumor necrosis factor therapy. Results from the British Society for Rheumatology Biologics Register. Arthritis Rheum 2006; 54 (8): 2368-76.

7. Listing J, Strangfeld A, Kary $\mathrm{S}$ et al. Infections in patients with rheumatoid arthritis treated with biologic agents. Arthritis Rheum 2005; 52 (11): 3403-12. 